\title{
Racial realities or bombast?
}

\section{When is it helpful to categorize people according to race?}

\section{Race: The Reality of Human Differences \\ by Vincent Sarich \& Frank Miele \\ Westview Press: 2004. 320 pp. $\$ 27.50$}

\section{Robert N. Proctor}

This is a disturbing book, especially given the stature of its primary author, Vincent Sarich, as one of the founding pioneers of molecular anthropology. In 1967, in a paper with Allan Wilson, Sarich, then a graduate student at the University of California, Berkeley, used a simple protein-molecular clock to show that humans share a common ancestor with the great apes from as recently as 5 million years ago - overturning previous estimates of more 20 million years.

Here he teams up with Frank Miele, a senior editor at Skeptic magazine, to lament the neglect of "racial realities" by social scientists. The voice is one of loners crusading against conventional wisdom, although the book also reads as if it were a legal brief prepared for use in court to counter affirmative action. The authors' 'case for race' draws heavily on contentious claims by raciologists such as Arthur R. Jensen and J. Philippe Rushton, notorious for having postulated natural racial hierarchies in intelligence, criminality, athletic performance, sexual endowment and the capacity to accumulate wealth. This is a shame, because there are good reasons to believe that certain aspects of race are very real, and that important questions of human origins, prehistoric migrations and medical therapeutics can be fruitfully addressed by properly re-examining human biovariation.

Here, though, we have an exercise in bombast and overstatement. The book begins by claiming that, throughout history, people have always had pretty much the same conception of race. Miele explains their methodology: "Vince suggested that I (Frank Miele) search the anthropology library at the University of California-Berkeley for examples of the way ancient civilizations ... described themselves and other races in their art, their literature, and their oral tradition. Did they distinguish races ... as we do today?" Based on this quick review, the authors conclude that people from ancient Egypt, Greece, Rome, India, China and the Islamic world all sorted peoples "based on the same set of characteristics - skin colour, hair form, and head shape" that we do today. As evidence, the authors display an Egyptian jug with a negroid head on one side and a rather European-looking face on the other, from which they infer a universal "common sense" reality of race.
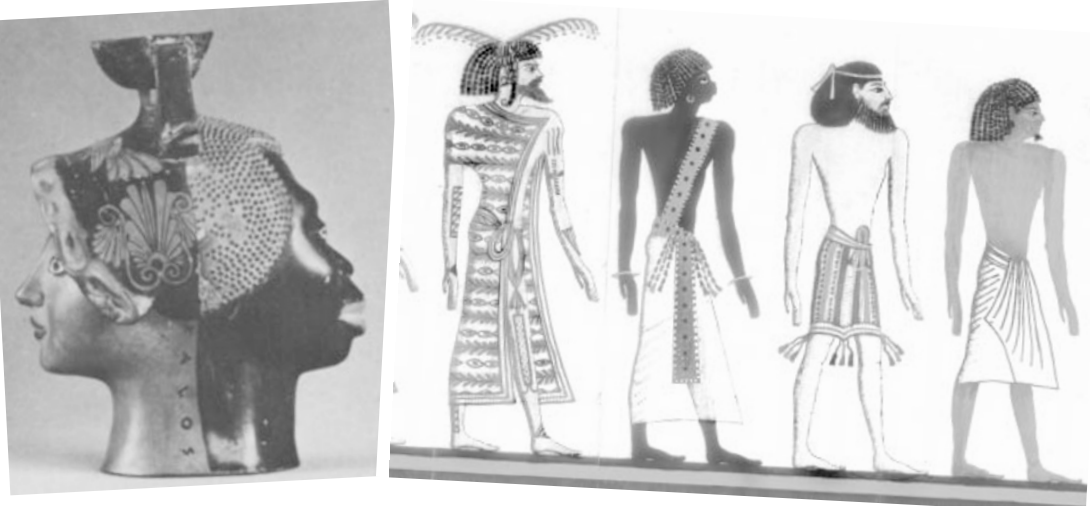

True colours? The Greeks and Egyptians seemed to be aware of differences in race.

Flaws in this book are so numerous that it would be difficult to list them all. Long passages are quoted without attribution, and many strong claims are presented with little or no supporting evidence. We hear that children as young as three classify people on the basis of racial characteristics that they already recognize as immutable. The authors postulate "an inborn tendency to sort people into groups" and a "module" in the human brain that predisposes people to distinguish an "us" from a "them". There are blanket assertions that "the Greeks believed in race" and that "few of us resent a rich kinsman or coethnic". Historians will be disturbed to hear that Giordano Bruno was burned at the stake for affirming that "the earth was the center of the universe", an assertion which, like several others in this volume, comes closer to the truth when inverted.

Stronger claims are made that border on the incendiary. In a chapter attacking affirmative action, the authors write that "a large number of white Americans harbor the suspicion that all minority members in high-status positions are there only because of affirmative action and not because of ability or achievement". A large number? Where's the evidence? The authors write that "All around the world downwardly mobile males who perceive themselves as being deprived of wealth, status, and especially females by up-and-coming members of a different race are ticking time bombs". Time bombs? Again, where's the evidence?

Sarich and Miele make similar claims in a discussion of South African plans under the apartheid regime to develop "pigmentation weapons" that would "target only black people”. After outlining how such weapons might be developed, the authors propose racial intermarriage as a "best defense" but also warn that "intermarriage, particularly of females of the majority group with males of a minority group, is the factor most likely to cause some extremist terrorist group to feel the need to launch such an attack". The authors add some old-style eugenics rhetoric, worrying about "plunging" birth rates in the United States and Western Europe and the "evolutionary irony lurking on the horizon" that, having conquered and colonized the world, Europeans and their descendants now risk bringing about "their own extinction" from having too few babies.

Towards the end of this book, the authors tell of a bioanthropologist colleague, Henry Harpending, who was travelling in the Kalahari and got stuck when his pick-up broke down. An ingenious bushman in the party suggested jacking up the vehicle and jumpstarting it by running a rope around the back tyres and pulling. The trick worked, and the authors are clearly puzzled that an African could have come up with such an imaginative solution, given "the mean sub-Saharan IQ of 70". Harpending's explanation is that "bushmen are really quick and clever" and in this respect quite different from their "black African neighbors". Sarich and Miele then ponder whether the development of agriculture may have dulled the intelligence of the continent's former hunter-gatherers.

What I found remarkable about this story, however, is how willing the authors are to accept this low figure for the sub-Saharan IQ, based on so little supporting evidence. The authors cite an apartheid-era study of a South African high school and an 'in press' literature review by Rushton and Jensen, ignoring the many ways that such a sweeping and grotesque generalization could be flawed.

The authors scoff at the idea of race as a social construct, but the historical account they present is full of idealized white-andblack polarities. The authors side with Ernst Haeckel over Rudolf Virchow, Madison Grant over Franz Boas, and Carleton Coon over Ashley Montagu. There is little effort to explore which of the myriad historical 
'realities' postulated for race might have alternative explanations.

I suspect that the impact of this book could be the opposite of the authors' intentions. There is much to be said for studying human genetic variability to explore questions of prehistoric ancestry and migration, and to investigate how different human populations respond to medical interventions. But the leap from these to immoderate speculations about the permanence of presentday inequalities is likely to give sceptics even more reason to question racial 'realities'.

Anthropology has a mixed history of dealings with human racial injustice (think of Carleton Coon's view that Africans became human some 200,000 years after white Europeans). The present book, so full of flim-flam and loose speculations, is more likely to re-arm than to deflate sceptics.

Robert N. Proctor is in the Department of History, Pennsylvania State University, University Park,

Pennsylvania 16802, USA.

\section{Plotting the downfall of society}

\section{Historical Dynamics: Why States \\ Rise and Fall \\ by Peter Turchin \\ Princeton University Press: 2003. 264 pp. \\ $£ 22.95, \$ 35$}

\section{Joseph A. Tainter}

In one of history's most extraordinary forecasts, the Greek historian Polybius in the second century $\mathrm{BC}$ predicted the demise of the Roman Empire some 600 years before it fell. Like others of his time, Polybius held a cyclical view of history in which societies, like biological systems, develop through growth, maturity, senescence and death. Polybius might be more celebrated today had he based his prediction on a different theory. Retrospectively, his forecast was no more challenging than anticipating the death of an ox.

Cyclical theories, like the phenomena they postulate, come and go. They have been espoused by historians from Polybius to Oswald Spengler. Serious historians have long held cyclical theories in disrepute, but now they're back, pushed in part by biologists who are accustomed to cycling or pulsing in such systems as predator-prey relationships and ecosystem development. C. S. Holling, for example, has developed a nuanced cyclical view in his 'panarchy' theory, and Kenneth Watt has explored cycling in population, resources and economics.

Beginning with the aphorism that a discipline usually matures only after it has developed mathematical theory, population biologist Peter Turchin attempts in this

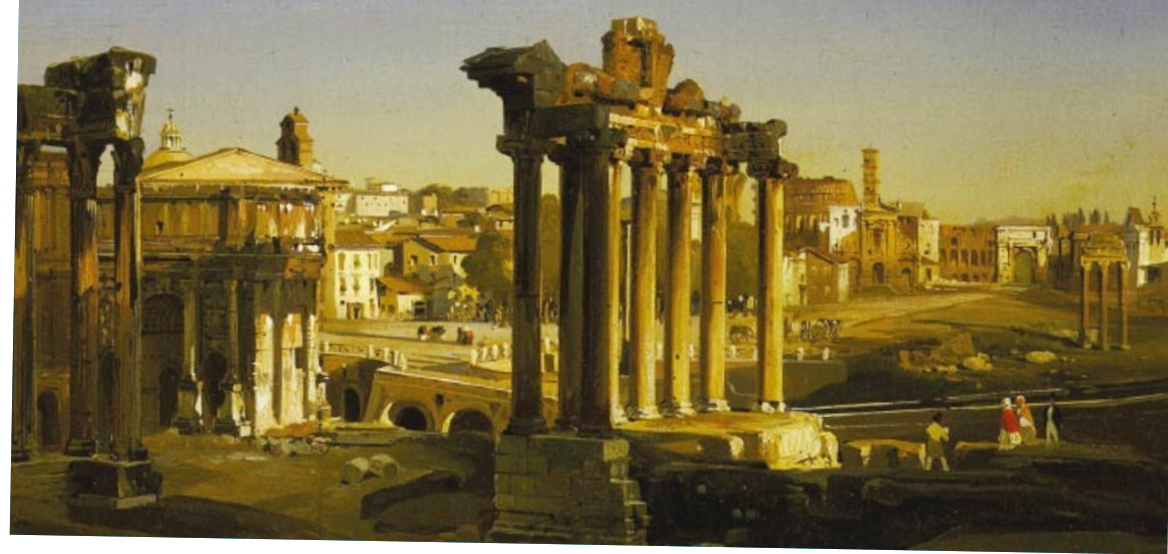

Pride comes before a fall: artist Ippolito Caffi shows how the Roman Empire was left in ruins.

book to develop quantitative cyclical theory in two main areas: territorial expansion and contraction in agrarian states, and population growth and decline in relation to political stability. He has taken care to write for historians: the verbal theories and mathematics are clearly presented, and the work is thoroughly researched and erudite.

Turchin bases his 'mature' approach on the work of the fourteenth-century Arab historian Ibn Khaldun, who sought to explain why desert nomads topple North African dynasties. Ibn Khaldun argued that the founders of dynasties rule well and tax lightly. Succeeding generations, though, develop a taste for luxury, resulting in higher taxation and declining welfare. Late-phase dynasties are challenged by desert nomads who have high degrees of asabiya, defined as collective solidarity or a capacity for collective action. Nomads with asabiya topple dynasties that lack it, starting the cycle anew. Ibn Khaldun perhaps meant his theory as a critique, but Turchin takes it literally. It might be called the 'team spirit' theory of history.

In his 'metaethnic frontier theory,' Turchin proposes that areas where imperial frontiers coincide with major ethnic boundaries function as 'asabiya incubators'. High asabiya allows a peripheral people to expand as an old empire contracts. Turchin builds this idea into quantitative simulations of expansion and contraction in European territorial history from AD 500 to 1900 . The quantification is built on ordinal scaling, judgemental assignment of values, and arbitrary cut-offs.

Like Polybius, Turchin can mimic actual outcomes despite having a dubious social theory. Metaethnic frontier theory is flawed by its primordial assumptions (for example, that ethnic groups are 'quintessential human groups' and that conflict is innate) and by failures of fact and logic. Turchin ignores problems of complexity in large societies, and asymmetrical warfare between states and non-states. States, of course, inculcate something akin to asabiya in their armed forces. Ask soldiers why they fight and they will answer: "For my buddies" — rather like nomads. Asabiya was strangely ineffective during the centuries when North African nomads failed to expel the Carthaginians, Romans, Vandals and Byzantines. And one wonders about the ethnic solidarity of Renaissance armies that were filled with mercenaries, a matter that Turchin ignores when he simulates European territorial changes.

'Demographic-structural theory' builds on Jack Goldstone's excellent work on population growth and state breakdown, and on Turchin's own experience in population biology. This exercise quantifies how political instability and population interact. Unsurprisingly, Turchin's models show that interaction between population dynamics and a state's fiscal health produces cycles of expansion and breakdown.

This theory is on firmer ground than asabiya, but much of the discussion remains simplistic. In his population model, Turchin treats élites like an inert organic mass that expands and contracts with resources, ignoring the organizational aspects of hierarchy. A need for organization may raise the proportion of élite administrators regardless of resources, as in the later Roman Empire.

Turchin cites archaeological settlement data from Roman Gaul that display two peaks and troughs. The relationship between the number of archaeological sites and population is complex, as Turchin acknowledges. If this pattern reflects population oscillations, he asserts, then unchecked population growth in the first peak led to insolvency and breakdown. In fact, neither peak reflects simple population growth. The first (from the first to the second century AD) came from Romanization and settlement of veterans, the second (in the fourth century) from changes in taxation.

Quodnonfecerunt historicifecerunt biologi 